https://dx.doi.org/10.4314/ijs.v19i2.2

Ife Journal of Science vol. 19, no. 2 (2017)

\title{
COMPARATIVE POLLEN ANALYSIS OF HONEYS FROM APIARY AND OPEN MARKETS IN NIGERIA AND BÉNIN REPUBLIC
}

\author{
${ }^{1,2}$ Orijemie Emuobosa Akpo \\ ${ }^{1}$ McDonald Institute for Archaeological Research, University of Cambridge, UK \\ ${ }^{2}$ Department of Archaeology and Anthropology, University of Ibadan, Ibadan, Nigeria \\ Email: orijemie5@yahoo.com. \\ Received: $24^{\text {th }}$ June, 2017; Accepted: $8^{\text {th }}$ September, 2017
}

\section{ABSTRACT}

There have been doubts as to the authenticity of honeys purchased in the open markets mainly due to sharp practices of vendors. Hence, pollen analysis was carried out on honeys from open markets and those from an apiary to ascertain the veracity of the claims. Eleven honey samples, six from the apiary and five from the open markets, were analysed for their pollen content. Pollen types and number in the apiary honeys varied between 7 and 13 and 57 and 64,000 respectively; the most dominant pollen types being those of Elaeis guineensis and herbaceous plants. Pollen types in the open market honeys on the other hand varied between 11 and 48 while counts varied between 626 and 241,623, and were dominated by pollen of Guinea savanna plants. Pollen assemblages in the apiary honeys reflected the surrounding vegetation of the apiary which was secondary forest as well as its production season. In contrast, pollen assemblages of all the open market honeys revealed their sources as being Guinea savanna zone. This however, indicates the vegetation of the producing locality of only one of the honeys and also contradicts the claim of a rainforest source for the others. Results from this study underscore the significance of melissopalynology in ascertaining sources of honeys, and highlight the importance of the Guinea savanna in beekeeping and honey production.

Key words: Pollen, Bees, Guinea savanna, Botanical origin, Honey, Melissopalynology

\section{INTRODUCTION}

Honey is a sweet food made by bees of the genus Apis; it is collected by beekeepers and consumed by humans. The earliest evidence of the use of honey by humans is from a 15,000-year-old rock painting of Altamira caves in northern Spain (Jones and Bryant, 1996). The benefits of honey to humans are numerous and include its use as an immune system booster. It is therefore important that only those of high quality are consumed. A reliable way of ascertaining the quality of honey is through melissopalynology (White et al. 1991). Several melissopalynological studies have been carried out in Nigeria including those of Agwu and Akanbi (1985); Agwu et al., (1989); Agwu and Okeke, (1997), Aina and Owonibi (2011), and Sowunmi, (1976). These studies mainly focused on honeys from open markets except those of Aina and Owonibi (2011), Adeonipekun (2012),
Kayode and Oyeyemi (2014) and Adeonipekun et al., (2016) who studied honeys from apiaries. There have been concerns as to the authenticity of honeys in open markets because of sharp practices by vendors who mix wild honeys and those from apiaries with sugar cane syrup and caramel. Therefore, pollen analyses of such "honeys" will give erroneous information about the bee foraging habits, and consequently present misleading information to bee keepers. This paper presents results of pollen study of authentic honeys from an apiary in south-western Nigeria, and compares the results with those obtained from the open markets from localities in Nigeria and Bénin Republic (Figure 1). It also ascertained the botanical and geographical origins of the respective honeys, and infers their possible production seasons. 


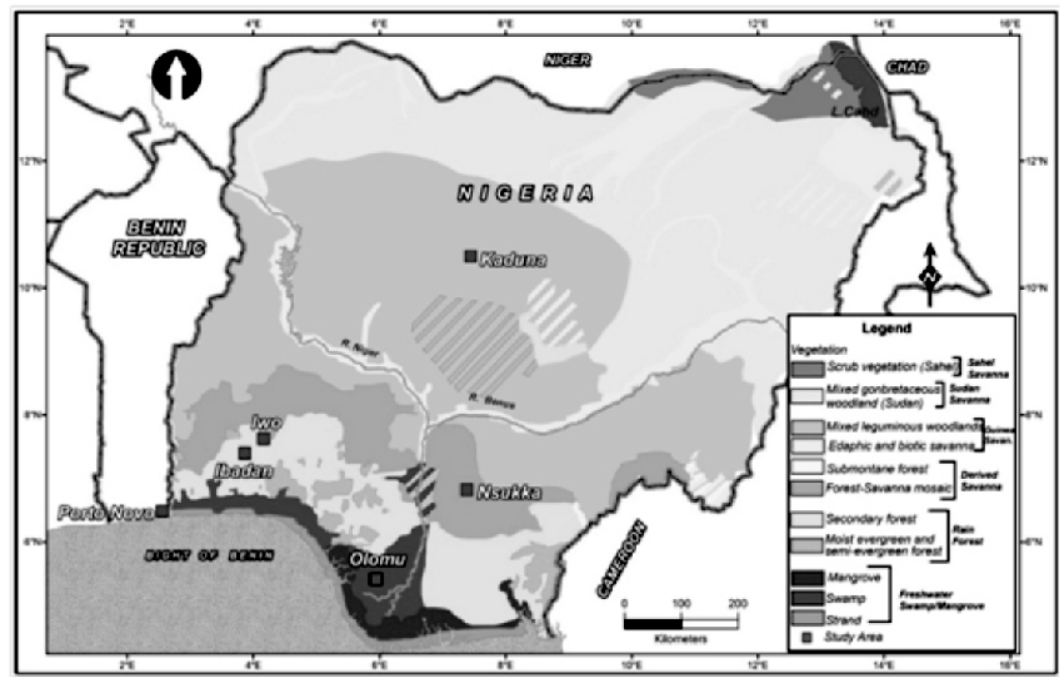

Figure 1. Map of the study area showing localities where honeys were collected and the vegetation belts of Nigeria

\section{MATERIALS AND METHOD}

Six Apis mellifera var. adansonii honeys were collected directly from different Kenyan top-bar hives in an apiary in Iwo (1-6), south-western Nigeria (Figures 1 and 2). One sample was obtained from an open market in Bénin Republic (Porto-Novo 7) while five other samples were purchased from vendors in open markets in four localities in Nigeria (Kaduna 8, Olomu 9, Ibadan 10 and Nsukka 11) (Figure 1). The vendors of these honeys in the open markets claim to have obtained their honeys directly from apiaries in their various localities.
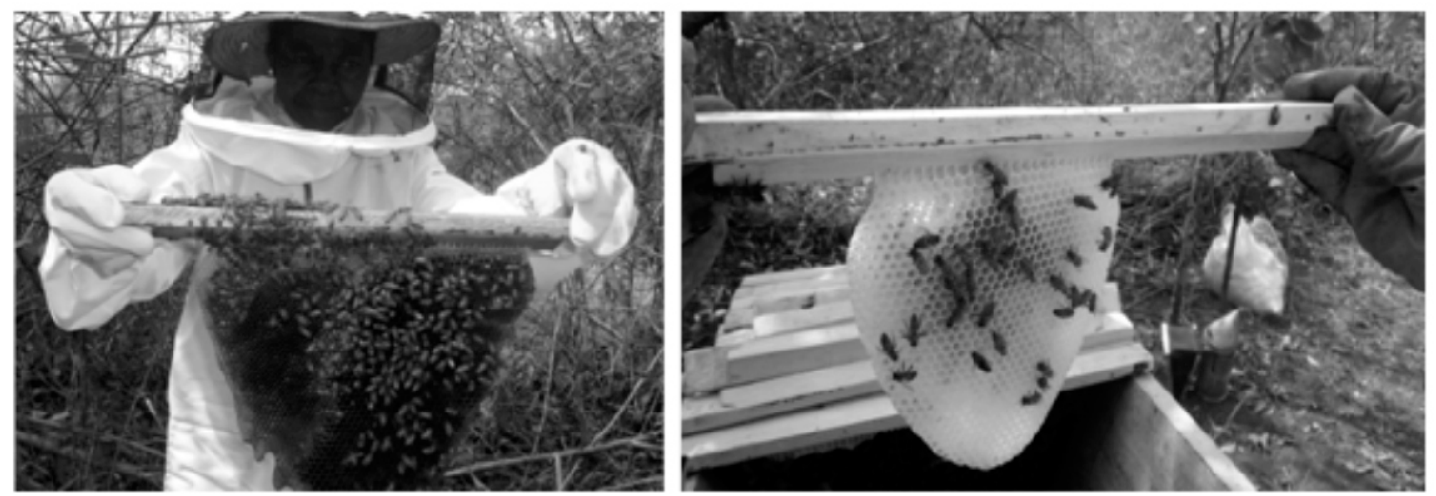

Figure 2. Honey combs from Kenya top-bar hives in the Iwo apiary

Vegetation types of honey source localities

Kaduna is located in the northernmost part of Guinea savanna zone; the vegetation is dominated by Borassus aethiopum, Protea spp., Acacia spp. and grasses. Ibadan and Iwo are located in secondary forests of south-western Nigeria although Iwo is on the boundary between secondary forest and derived savanna. The vegetation there is characterised by rainforest plants such as Adansonia digitata, Elaeis guineensis, Alchornea cordifolia, A. latifolia, Bombax buonopozense, Bosquiea angolensis, Piptadeniastrum africanum, Spondias mombin, and some savanna plants notably Lannea sp., Lophira cf. lanceolata, Hymenocardia acida, Nauclea cf. latifolia, Phyllanthus discoideus and Vitellaria paradoxa. Nsukka, on the other hand, is in the forest-savanna transition zone of south-eastern Nigeria; the dominant plants being Bombax costatum, Hymenocardia acida, Parinari kerstingii, Parkia biglobosa, Lannea microcarpa and Vitellaria paradoxa. Olomu is in the freshwater swamp forest zone of southern Nigeria the vegetation of which is characterised by Nauclea diderrichii, Spondianthus preussii, Symphonia globulifera, Elaeis guineensis, Raphia hookeri and R. vinifera, while Porto-Novo is located in the freshwater and mangrove swamps of 
southern Bénin Republic with Avicennia africana, Conocarpus, Pandanus candelabrum, Elaeis guineensis, Cocos nucifera, Hibiscus tiliaceus and grasses (Paspalum distichum and Sporobolus virginicus) as dominant plants (Allio and Schut, 2011). Ten grammes of each sample was processed according to standard procedures (Louveaux et al. 1970). Actual counts and the percentages of pollen types, represented as phyto-ecological groups, in the honeys are shown in table 1 and figure 3 respectively. Photomicrographs of pollen (Figure 4) were taken with oil immersion x100 objective of a light microscope, and the colours of the honeys (Table 2) were determined using the Munsell Colour Chart.

Table 1. Occurrence of pollen in the different honey samples

\begin{tabular}{|c|c|c|c|c|c|c|c|c|c|c|c|}
\hline Palynomorphs/Samples & Iwo1 & Iwo2 & Iwo3 & Iwo4 & Iwo5 & Iwo6 & $\begin{array}{l}\text { Porto } \\
\text { Novo } 7\end{array}$ & $\begin{array}{l}\text { Kaduna } \\
8 \\
\end{array}$ & $\begin{array}{l}\text { Olomu } \\
9\end{array}$ & $\begin{array}{l}\text { Ibadan } \\
10\end{array}$ & $\begin{array}{l}\text { Nsukka } \\
11\end{array}$ \\
\hline Acacia cf. sieberiana & & & & & & & 6435 & & & & 74 \\
\hline Acanthaceae & & & & & & & 11 & & & & 23 \\
\hline Acanthaceae 2 & & & & & & & & & & & 17 \\
\hline Adenia cissampeloides & & & & & & & 2553 & & & 4 & 4103 \\
\hline Afzelia africana & & & & & & & & & & & 83 \\
\hline Alchornea cf. cordifolia & & 497 & 19 & 513 & & & & & 239 & 15 & 2863 \\
\hline Annona sp. & & & & & & & & & & & 15 \\
\hline Anonidium mannii & & & & & & & 11 & 3 & & & \\
\hline Antidesma sp. & & & & & & & & & & 4 & 1369 \\
\hline Arecaceae & & & & & & & 429 & & & & \\
\hline Aspilia africana & 1 & & & 13 & & & & & & & \\
\hline Asteraceae & & & & & & & 17 & 13 & 161 & & 3481 \\
\hline Azadiractha indica & & & & & & & & 7 & & & \\
\hline Bignoniaceae & & & & & & & 13 & & & & \\
\hline Bligbia sapida & & & & & & & & 257 & & 6 & \\
\hline Bombax buonopozense & & & & & & & 13524 & & & & \\
\hline Bombax costatum & & & & & & & 49 & & & & \\
\hline Borassus aethiopicum & & & & & & & 409 & & 155 & & \\
\hline Borreria scabra & & & & & & & 51 & & & & \\
\hline Borreria sp. & & & & & & & 2 & & & & \\
\hline Bosquiea angolensis & & & & & & & 12558 & & & & \\
\hline Bridelia ferruginea & & & & & & & & 14 & & 7 & \\
\hline Caesalpiniaceae (Fabaceae) & & & & & 13 & 5 & & & & & \\
\hline Cantbium subcordatum & & & & & & & 253 & & & & \\
\hline Cassia cf. tora & & & & & & & 5796 & & & & \\
\hline Ceiba pentandra & & & & & & & 506 & 5 & & & 91 \\
\hline Celtis sp. & & & & & & & 15 & 13 & & & \\
\hline Cf. Clematis sp. & & 11 & & & & & & & & & \\
\hline Choriosa sp. & & & & & & & & & & & 73 \\
\hline Chromolaena odorata & & 187 & 2308 & 195 & 23107 & 30039 & & & & 4 & \\
\hline Chrysophyllum albidum & & & & & & & 966 & & & & \\
\hline
\end{tabular}

\section{RESULTS}

Pollen counts and variety of pollen types

A total of 94 pollen species were identified from the eleven samples studied (Table 1); they belong to seventy-two genera and thirty-five families. The number of pollen grains and the variety of pollen types in the apiary were low; they ranged from 57 to about 64,000 , and 25 species respectively. Pollen counts in the five honeys from the open markets ranged from 626 to 241,623 with a total of 84 pollen types. The number and pollen types were most abundant in the Kaduna, Nsukka and PortoNovo samples which had 74,334-241,623 pollen counts with 28,44 and 48 pollen types respectively. In contrast, those of Olomu and Ibadan had 11 and 15 pollen types with 4,131 and 626 pollen counts respectively. 
Table 1. Occurrence of pollen in the different honey samples contd.

\begin{tabular}{|c|c|c|c|c|c|c|c|c|c|c|c|}
\hline Palynomorphs/Samples & Iwo1 & Iwo2 & Iwo3 & Iwo4 & Iwo5 & Iwo6 & $\begin{array}{l}\text { Porto } \\
\text { Novo } 7\end{array}$ & $\begin{array}{l}\text { Kaduna } \\
8\end{array}$ & $\begin{array}{l}\text { Olomu } \\
9\end{array}$ & $\begin{array}{l}\text { Ibadan } \\
10\end{array}$ & $\begin{array}{l}\text { Nsukka } \\
11\end{array}$ \\
\hline Combretaceae/Melastomataceae & & 103 & 341 & 32 & & & 87906 & 53130 & 664 & 11 & 8217 \\
\hline Commelina sp. & & & & 17 & & & 1265 & & & & 83 \\
\hline Crassocephalum crepidiodes & & & 32 & & & & & & & & \\
\hline Cucurbitaceae & & & & & & & 19 & 9 & & & \\
\hline Cussonia cf. barteri & & & & & & & & 81 & & & \\
\hline Cyperaceae & & & & & & & & & & & 21 \\
\hline Daniellia oliveri & & & & & & & 271 & 6 & & & 851 \\
\hline Delonix regia & & & & & & & & & & & 61 \\
\hline Desmodium $\mathrm{cf}$. ramosissimum & & & & & & & 4719 & 86 & & & 1919 \\
\hline Detarium senegalense & & & & & & & 7 & & & & \\
\hline Diospyros sp. & & & & & & & & 6 & & & \\
\hline Dombeya buettneri & & & 37 & & 39 & & 253 & & & & \\
\hline Elaeis guineensis & & 79 & 954 & 331 & 24705 & 32117 & 598 & 2317 & & 151 & \\
\hline Entada abyssinica & & & & & & & 2145 & 12871 & 331 & & 5478 \\
\hline Erythrina sp. & & & & & & & & & & & 39 \\
\hline Euphorbia hirta & & 22 & & & & & & & & & \\
\hline Flabellaria paniculata & & & & & & & & & & & 21 \\
\hline Gardenia tenuifolia & & & & & & & 7 & & & & \\
\hline Grewia carpinifolia & & & & & & & 13 & & & & \\
\hline Grewia megalocarpa & & & & & & & & & & & 471 \\
\hline Grewia sp. & & & & & & & & & & & 23 \\
\hline Hippocratea $\mathrm{cf}$ africana & & & & & & & 4073 & & & & 192 \\
\hline Hymenocardia acida & & & & & & & 10626 & 610 & 121 & 13 & 2863 \\
\hline Hyphaene thebaica & & & & & & & & & & & 125 \\
\hline Irvingia gabonensis & & 61 & & & & & & & & & \\
\hline Isoberlinia sp. & & & & & & & 2898 & & & & \\
\hline Jatropha sp. & & & & & & & & & & & 33 \\
\hline Justicia insularis & & & & & & & 3 & & & & \\
\hline Kigelia africana & & & & & & & & 5 & & & \\
\hline Lannea sp. & & 23 & & & & & 7728 & 8151 & 974 & & 10958 \\
\hline Lophira cf. lanceolata & & & & 149 & & & & & & & 3819 \\
\hline Mangifera indica & & & & & & & & & & & 79 \\
\hline Mimosa pigra & & & & & & & & & & & 1317 \\
\hline Mimosa pudica & 2 & & 19 & & & & & & & & \\
\hline Moraceae & & & & & & & & & 159 & & \\
\hline Myrtaceae & & & & 33 & & & & 858 & & & 4001 \\
\hline Nauclea cf. latifolia & & & & 171 & & & 17388 & & 677 & & 4143 \\
\hline Papilionaceae (Fabaceae) & 3 & & & & & & & 4 & & 9 & \\
\hline Papilionaceae type (Fabaceae) & & & & & & & & & & 11 & \\
\hline Parinari cf. kerstingii & & & & & & & 2530 & 1495 & 151 & & 475 \\
\hline Parkia biglobosa & & & & & & & 12154 & 33 & & & 69 \\
\hline Paullinia pinnata & & & & & & & & & & & 113 \\
\hline Pavetta cf. owariensis & & & & & & & 7781 & 172 & & 5 & 4587 \\
\hline Pericopsis sp. & & & & & & & 3767 & & & & \\
\hline Phyllanthus discoideus & & & & 21 & & & & & 498 & 16 & 4469 \\
\hline Piliostigma thonningii & & & & & & & & & & & 2877 \\
\hline Piptadeniastrum africanum & & & & & & & 16422 & 45 & & & \\
\hline Poaceae & 19 & & & 31 & 7 & 9 & 25 & 7 & & & 93 \\
\hline Protea sp. & & & & & & & 1 & & & & \\
\hline Sapindaceae & 3 & & & & & & & & & & \\
\hline Sida acuta & & & & & 37 & 48 & & & & & \\
\hline Spondias mombin & & & & & & & 13 & & & & \\
\hline Talinum triangulare & 8 & 53 & & 137 & 18 & 23 & & & & & \\
\hline Tridax procumbens & & & & & & & 53 & & & 363 & \\
\hline Triumfetta cordifolia & & & & & & & & 8 & & & \\
\hline Triumfetta sp. & 21 & & 33 & 28 & 903 & 1177 & & & & & \\
\hline Uapaca sp. & & & & & & & 1387 & & & & 41 \\
\hline Vernonia amygdalina & & & & & 434 & 733 & & & & & 33 \\
\hline Vernonia frondosa & & & & & & & & & & & 293 \\
\hline Vitellaria paradoxa & & & & & & & 8694 & 1373 & & 7 & \\
\hline Vitex cf. doniana & & & & & & & & 5 & & & \\
\hline Zanthoxyllum ranthoxyloides & & & & & & & & & & & 3825 \\
\hline Zea mays & & & & & & & & & & & 418 \\
\hline Unidentified & & & & & & & 87 & & & & 135 \\
\hline Total & 57 & 1036 & 3743 & 1671 & 49263 & 64151 & 241,623 & 81,582 & 4131 & 626 & 74,334 \\
\hline
\end{tabular}




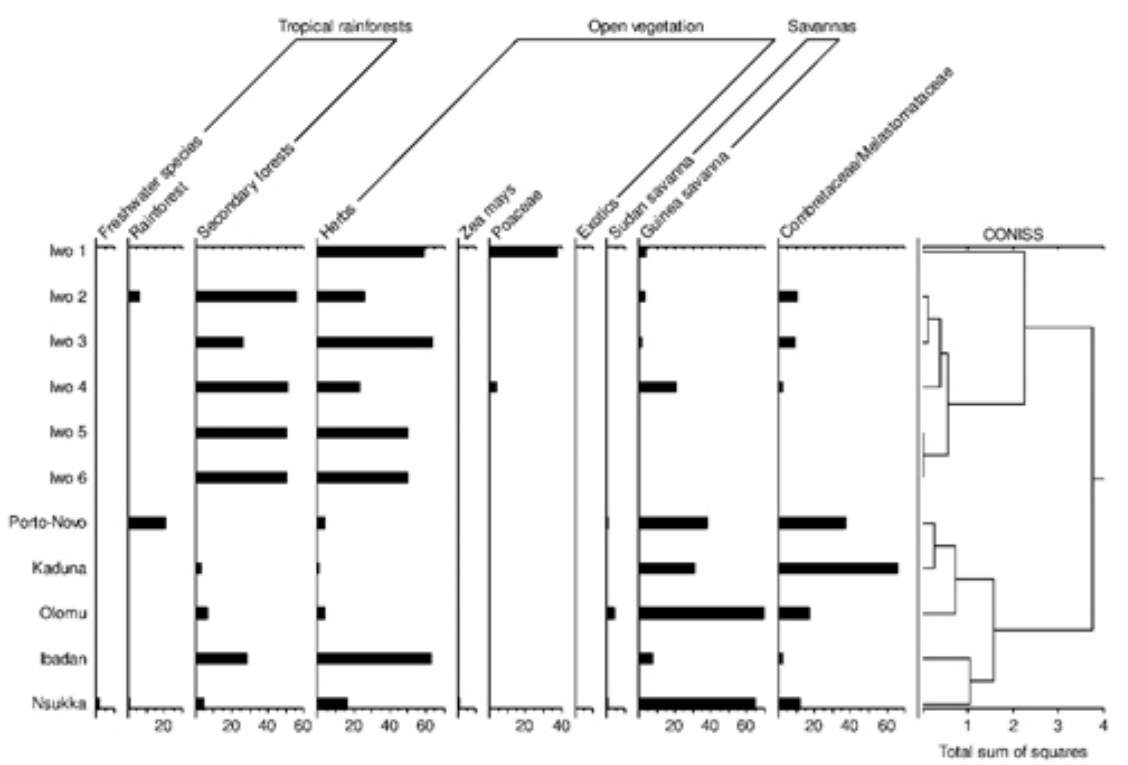

Figure 3. Pollen diagram of the Iwo apiary and Open market honeys

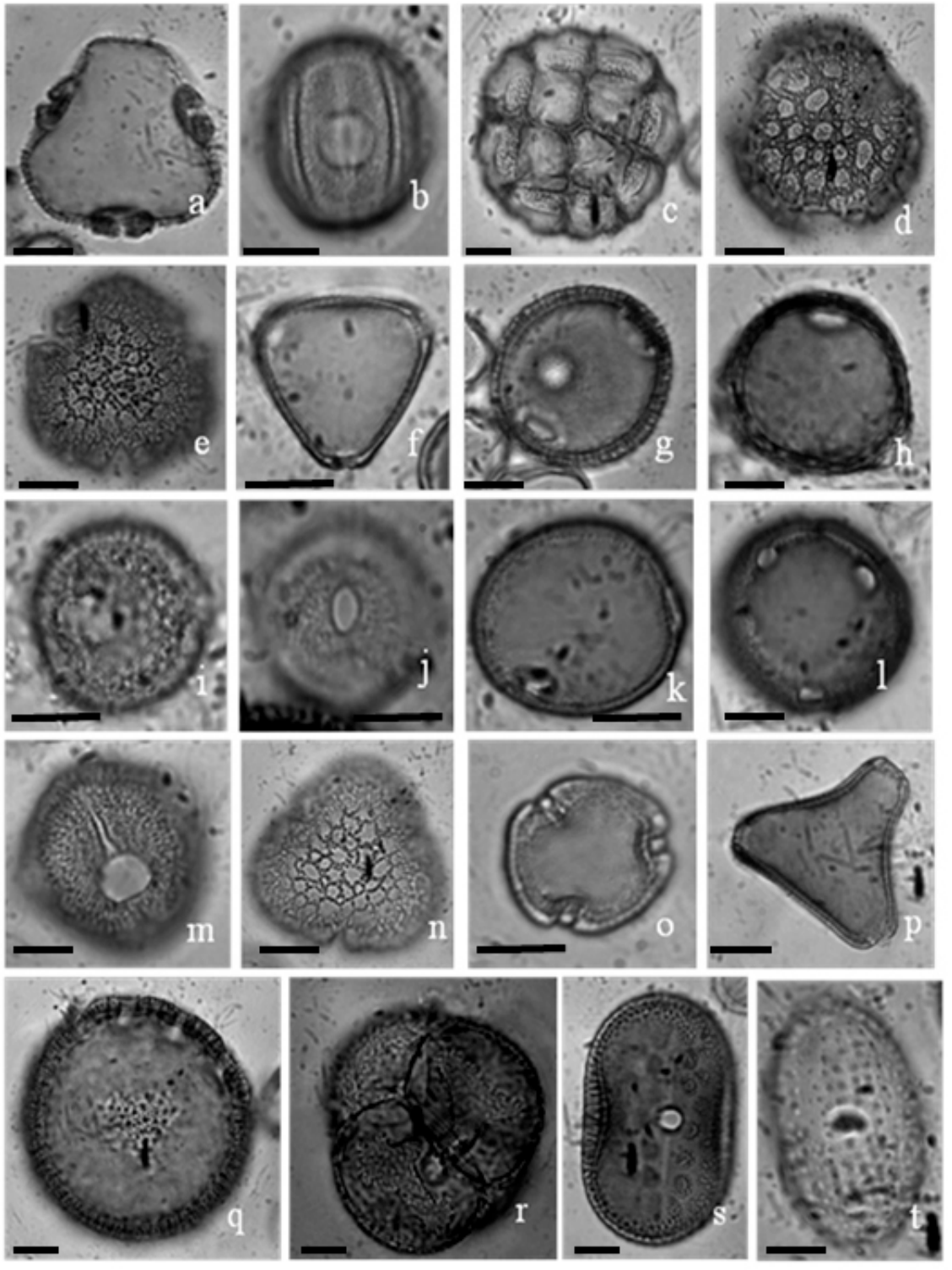

F i g u r e 4 . Photomicrographs of pollen from the honey samples. a. Unidentified, $\mathbf{b}$. C o m b r e t a c e a e / Melastomataceae, c. Acacia cf. sieberiana, d. Delonix regia, e. Bombax buonopozense, $\mathbf{f}$. Protea sp., g. Canthium subcordatum, h. Erythrina sp., i. Uapaca sp., j. Nauclea cf. latifolia, k. Hymenocardia acida, 1. Flabellaria paniculata, m. Mangifera indica, $\mathbf{n}$. Bombax costatum, o. Alchornea sp., p. Paullinia pinnata, q. Borreria scabra, $\mathbf{r}$. Gardenia tenuifolia, s. Justicia insularis, t. Commelina sp. Scale bar $=10 \mu \mathrm{m}$ 


$\begin{array}{ll}\text { Table 2. Colours of } & \text { the honey samples } \\ \text { Honey sample } & \text { Colour } \\ \text { Iwo 1 } & \text { Dark reddish brown } \\ \text { Iwo 2 } & \text { Red } \\ \text { Iwo 3 } & \text { Dark reddish brown } \\ \text { Iwo 4 } & \text { Yellow } \\ \text { Iwo 5 } & \text { Yellowish red } \\ \text { Iwo 6 } & \text { Strong brown } \\ \text { Porto-Novo 7 } & \text { Brown } \\ \text { Kaduna } 8 & \text { Red } \\ \text { Olomu 9 } & \text { Yellowish brown } \\ \text { Ibadan 10 } & \text { Reddish brown } \\ \text { Nsukka 11 } & \text { Reddish brown }\end{array}$

\section{DISCUSSION}

Plants most visited by the bees and inference of their habitats

Apiary Honeys

Based on the relative abundance of the pollen contained in the honey samples it seems that the plants most visited by the bees were Elaeis guineensis, (the oil palm), Chromolaena odorata, and Alchornea cf. cordifolia for all the samples except sample 1. For sample 1, the plants most visited were Triumfetta sp., Aspilia africana and Mimosa pudica (all common weeds), and Poaceae (grasses). It is significant to note that Elaeis guineensis, Chromolaena odorata and Alchornea cf. cordifolia, were completely absent from the honey in sample 1. In addition to the pollen types highlighted above, others were those of common weeds, and edible plants, i.e. Tridax procumbens, Vernonia amygdalina and Irvingia gabonensis (African wild mango, the seeds of which are used in cooking ogbono soup, a common southern Nigerian delicacy). The pollen of Combretaceae/Melastomataceae was also common. These pollen grains are very similar such that it is difficult to distinguish them from one another hence impossible to determine the plants in these families which were visited by the bees. However, it was observed in the apiary that bees foraged Terminalia superba and T. catapa trees during their flowering seasons. The abundance of Elaeis guineensis (the oil palm) and Alchornea cf. cordifolia are indicative of forest regrowth, while the abundant weeds are indicative of abandoned or un-weeded farmland. Vernonia amygdalina and Irvingia gabonensis are suggestive of farming. It appears the bees foraged cultivated areas within the forest zone where most of the forest trees had been cleared, making room for the proliferation of Alchornea cf. cordifolia and Elaeis guineensis and some savanna trees. It should be emphasised that E. guineensis might have been deliberately cultivated or just protected. Vernonia amygdalina and Irvingia gabonensis are suggestive of farming. In addition, the occurrence of pollen of Poaceae (grasses) as well as those of Guinea savanna (Lannea sp., Lophira cf. lanceolata, Nauclea cf. latifolia and Phyllanthus discoideus) reflects both the presentday vegetation of the apiary as well as that of the Iwo region.

\section{Open market Honeys}

The pollen of Combretaceae/Melastomataceae and Hymenocardia acida were present in all the samples while those of Asteraceae, Tridax procumbens, Entada cf. abyssinica, Lannea sp., Parinari kerstingii and Pavetta cf. owariensis, Daniellia oliveri, Lophira cf. lanceolata, Nauclea cf. latifolia and Piliostigma thonningii were well represented. All these including some members of the Combretaceae/Melastomataceae are natural to the Guinea savanna which is an indication that the honeys were probably from the zone. In addition to those already mentioned above, other important plants visited by the bees included those of economic importance to humans such as Elaeis guineensis (oil palm), Parkia biglobosa (locust bean) and Vitellariaparadoxa (Shea butter). It is not certain if they were visited for their nectar, pollen or both. It has been suggested that windpollinated plants such as Elaeis guineensis (Agwu et al., 1989) and Poaceae (Kayode and Oyeyemi, 2014) are visited for their pollen. Tiwari et al., (2012) found similar results from Uttarakashi district in India where most pollen-sources are from wind-pollinated plants. However, Sabo et al., (2011) opined that the dominant pollen in honey represents nectar sources. This is in contrast to the results of this study because Elaeis guineensis and Poaceae, both wind-pollinated plants, dominated in Iwo 5 and 6, and in Iwo 1 respectively. These plants are major sources of pollen for honey bees in Nigeria.

The vendors' claims that the Porto-Novo and Olomu honeys were produced in the named localities (i.e. Porto-Nov and Olomu) are in sharp contrast to the pollen evidence. Porto-Novo is in the coastal region which consists of tidal marshes and lagoons. Its vegetation is dominated by 
freshwater swamps (Pandanus candelabrum), scattered mangroves (Avicennia and Conocarpus), Elaeis guineensis, Cocos nucifera, Hibiscus tiliaceus and abundant grasses (Paspalum distichum and Sporobolus virginicus) (Allio and Schut, 2011). Grasses were poorly represented in the Porto-Novo sample while no pollen of mangrove swamp forest, coastal vegetation, freshwater and secondary forest (particularly Elaeis guineensis) was recovered from it. It is likely that this honey was brought to Porto-Novo from the Guinea savanna zone. Similarly, Olomu is an Urhobo community in the freshwater swamps forests of Delta State, southern Nigeria. Elaeis guineensis (oil palm), Hevea brasiliensis (rubber tree) and Manibot esculentus (cassava) are common economic plants there. The absence of these pollen in this sample, Elaeis guineensis in particular, and abundance of Guinea savanna pollen indicate that the source of the honey is Guinea savanna. The Kaduna sample was characterised by pollen of plants in the transition limits of the Guinea-Sudan savanna (Borassus aethiopum, Hyphaene thebaica and Protea sp.), while the Ibadan and Nsukka honeys were characterised by pollen from a mosaic of secondary rainforest and grasslands. Nsukka is located on the Enugu Scarp, 300-500 $\mathrm{m}$ above sea level hence the occurrence of the pollen of freshwater species (Cyperaceae and Mimosa pigra) as well as the pollen of Zanthoxyllum zanthoxyloides, a plant of coastal vegetation, in the sample was unexpected.

Regarding the fewer varieties recorded in the Iwo honeys, one possible explanation might be that the bees got enough pollen and nectar from the few plants visited in the vicinity. A second possibility might be that they probably visited other plants for nectar only. The lower numbers might be due to several factors, especially the following two: (1) perhaps not much pollen was stored in the cells, most of it having been used up in feeding the brood; (2) if indeed much pollen was stored in the cells, then perhaps during the harvesting of the honey much of the pollen did not get mixed with the honey. A comparison between the two sets of honeys reveals the following: Firstly, certain pollen types namely Alchornea cf. cordifolia, Elaeis guineensis and Combretaceae/ Melastomataceae occurred in both groups of honeys except that of Iwo sample 1. Secondly, despite this occurrence, the apiary honeys were grouped differently from those of the open market when subjected to cluster analysis (Figure 2). Two groups, 1 and 2, are delineated; the apiary honeys constitute group 1 while group 2 consists of the open market honeys.

The main difference, along with those mentioned earlier, lie in the fact that firstly, although some pollen of Guinea savanna pollen such as those of Lannea sp., Lophira cf. lanceolata, Phyllanthus discoideus and Nauclea cf. latifolia were present in the apiary honeys, the most dominant pollen were Elaeis guineensis, Alchornea cf. cordifolia and herbaceous elements such as Chromolaena odorata, Talinum triangulare and Triumfetta sp. In contrast, those of open markets are dominated by the pollen of Guinea savanna trees such as Hymenocardia acida, Lannea spp., Entada cf. abyssinica and Parinari cf. kerstingii. In other words, the honeys in each group most likely derive from the inferred or similar ecological areas. This corroborates the earlier inference that the PortoNovo and Olomu samples were not produced in localities situated in the rainforest zone but "imported" from Guinea savanna. Secondly, the apiary honey contained fewer pollen types (25) than those from the open markets (84). The latter result is similar to those of other honeys from open markets in Nigeria which revealed higher number of pollen types (Ige and Modupe, 2010). Honeys with low pollen number and types had hitherto been assumed to be adulterated but this might not be the case judging from the low number and types from the Iwo honeys. The pollen types (25) from the apiary are consistent with those from bee hives in some localities in south-western Nigeria where pollen diversity ranged between 15 and 29 (Kayode and Oyeyemi, 2014; Adeonipekun et al., 2016), and 21 and 29 (Adeonipekun, 2012). However, when honeys are mixed or adulterated, their pollen contents (quantity and quality) could be reduced by fractions. For instance, when they are mixed with burnt sugarcane syrup, such honeys contain high amount of charred epidermal cells of grasses and charcoal particles. Mixing honeys from two different ecological zones could increase the number and types of pollen substantially. None of these were noted in the honeys studied.

The pollen results revealed few pollen of forest plants which suggests that little honey comes from 
the forest zone which corroborate those of Agwu and Akanbi, (1985), Agwu et al., (1989), Agwu and Okeke (1997), and Sowunmi, (1976). Although the reasons bees favour savanna plants have not been adequately investigated it appears this phenomenon is related to the open and dry nature of the savanna which is more suitable for bee flight and pollination activities (Agwu and Okeke, 1997). In addition, the honey bees' preference for open environments may be linked to their ancestry having evolved during the Eocene-Oligocene boundary (Engel, 1998; Han et al., 2012). In West Africa, this period was characterised by major marine regressions and open landscape in the hinterland (Digbehi et al.,2012).

At this stage, no categorical inference can be made yet about the colour of the honey especially in view of the fact that when the pollen of both Elaeis guineensis, (the oil palm) and Chromolaena odorata, constituted $97.0 \%$ (Iwo sample 5) and 96.9\% (Iwo sample 6), of the pollen count, the colours of the honey were yellowish red and strong brown respectively. Similarly, the pollen of Elaeis guineensis and Tridax procumbens constituted $82 \%$ of the pollen count of the Ibadan honey which was reddish brown.

The apiary honeys were produced in the months of December-February and subsequently harvested in the months following. This is reflected in the flowering seasons of the dominant pollen types in the honeys. Elaeis guineensis flowers between October and December; Talinum triangulare from January-February and Chromolaena odorata flowers between June and July (Hutchinson and Dalziel, 1958-1972). For the open market honeys, majority of the parent plants of the pollen flowers between December and February; this is followed by those that flower between March and May while very few flower between June and November. The months of December-February are periods of high bee foraging and honey production. These months are the peak of the dry season in West Africa, and are known as the best period for honey flow in the tropics (Crane, 1980). The months of March to May are equally important but perhaps represent secondary periods; these months constitute bee foraging period in southern Europe (Furness, 1994). Similarly, two seasons each of honey production
(March-May and October-Nov) were indicated in Indian honeys (Tiwari et al., 2012) and those of April and July-Sept for Chinese honeys (Song et al., 2012). In Nigeria, Agwu and Akanbi, 1985) found that the production season of honey is from September-April. Agwu et al., (1989) stated that Nsukka and savanna honeys are produced between October and May, and October-March (Agwu and Okeke, 1997) respectively. Similarly, Aina and Owonibi, (2014) found that bees collect pollen pellets between April and January. These reports from Nigeria are broadly consistent with those of the present study.

\section{CONCLUSION}

Pollen analysis of honey samples from an apiary and open markets in Nigeria and Bénin Republic was carried out. The apiary honeys were different from those of the open markets in that the former had fewer (25) pollen types compared to the latter which had much diverse (84) pollen types. Based on the relative abundance of the pollen of Elaeis guineensis, Alchornea cf. cordifolia, and herbaceous taxa in the Iwo honeys it is inferred that these constituted the plants most visited by the bees. Their occurrence also reflected the vegetation of the apiary which lies within the forest zone but has been extensively cleared and cultivated. In contrast, those of open markets were dominated by Guinea savanna plants. The geographical origins of at least four of the open market samples (Ibadan, Nsukka, Olomu and Porto-Novo) are the Guinea savanna zone in Nigeria and the northern part of Bénin Republic. This contradicts the vendors' claim of a rainforest source for the Olomu and Porto-Novo honeys. The fifth sample (Kaduna) appears to be from the northern Guinea savanna zone of Nigeria.

\section{ACKNOWLEDGEMENTS}

Appreciation goes to Mr Oluwafemi Kesington of Earthly Produce Limited Iwo, and Mrs. R. D. Orijemie and Prof S. O. Ogundele for supplying some of the honey samples. The anonymous reviewer is hereby acknowledged.

\section{REFERENCES}

Adeonipekun, P. A. 2012. Palynology of honeycomb and a honey sample from an apiary in Lagos, Southwest Nigeria. Asian Journal of Plant Science and Research 2: 274- 
283.

Adeonipekun, P. A., Adeniyi, T.A. and Eden, D. 2016. Antimicrobial Properties and Melissopalynology, Proximate and Elemental Analyses of Honey Samples from Three Different Ecozones in Nigeria. NotSciBiol. 8 (3): 326-333.

Agwu, C. O. C., and Akanbi, T. O. 1985. A Palynological study of honey from four vegetation zones of Nigeria. Pollen et Spores 27:335-348.

Agwu, C. O. C., and Okeke, G. I. 1997. Pollen analytical and thin-layer chromatographic study of honey from three savanna zones of Northern Nigeria. Nigerian Journal of Botany 10:25-36.

Agwu, C. O. C., Obuekwe, A. I., and Iwu, M. M. 1989. Pollen analytical and thin-layer chromatographic examination of Nsukka (Nigeria) honey. Pollen et Spores 31: 29-43.

Aina, D. O., and Owonibi, K. 2011. Beekeeping Prospects: Palynology and the Environment. Advances in Applied Science Research 2: 79-85.

Allio, A., and Schut, M. 2011. Porto-Novo 2011. A Strategy and urban design for the city centre. Atelier international de maitrise d'oevre urbaine

Crane, E. (1980) (Ed.). Honey: A Comprehensive Survey. London, UK. Heinemann.

Digbehi, B. Z, Doukoure, M., Tea-Yassi, J., Yao, R. K., Yao, J. P., Kangah, D. K., and Tahi, I. 2012. Palynostratigraphy and palaeoenvironmental characterization and evidence of Oligocene in the terrestrial sedimentary basin, Bingerville area, Southern Côte d'Ivoire, Northern Gulf of Guinea. African Journal of Environmental Science and Technology 6: 28-42.

Engel, M. S. 1998. Fossil honey bees and evolution in the genus Apis (Hymenoptera: Apidae). Apidologie 29:265-281

Furness, C.A. 1994. The extraction and identification of pollen from a Beeswax Statue. Grana 33: 49-52.

Han, F., Wallberg, A. and Webster, M. T. 2012. From where did the Western honeybee
(Apis mellifera) originate? Ecol Evol. 2: 1949-1957.

Hutchinson, J. and Dalziel, J.M. 1958-1972. Flora of West Tropical Africa. Vols I-III. Millbank, London, S.W. 1. Crown Agents for Oversea Governments and Administrations.

Ige, O. E., and Modupe T. O. 2010. Pollen Characterisation of Honey Samples from North Central Nigeria. Journal of Biological Sciences 10: 43-47.

Jones, G.D. and Bryant, V. M. 1996. Melissopalynology, In: Jansonius, J and D.C. McGregor, (Eds.), Palynology: Principles and applications; American Association of Stratigraphic Palynologists Foundation 3: 933-938.

Kayode, J., and Oyeyemi, S. D. 2014. Pollen Analysis of Apis mellifera Honey Collected from Nigeria. American Journal of Agriculture and Forestry 2: 226-231

Louveaux, J., Vorwohl, G., and Maurizio, A. 1970. Methods of Melissopalynology. Bee World 51:125-138.

Sabo, M., Potočnjak, M., Banjari, I., and Petrović, D. 2011. Pollen analysis of honeys from Varaždin County, Croatia. Turk J. Bot 35: 581-587.

Song, X., Y. Yao and Yang, W. 2012. Pollen Analysis of Natural Honeys from the Central Region of Shanxi, North China. Plos One, 7 (11) e 49545 , doi:10.1371/journal.pone.0049545.

Sowunmi, M. A. 1976. The potential value of honey in Palaeopalynology and Archaeology. Review of Palaeobotany and Palynology 21:171-185.

Tiwari, J. K., Gairola, A., Tiwari, P., and Ballabha, R. 2012. Pollen analysis of some honey samples from District Uttarakashi in Garhwal, Himalaya, India. Asian J. Exp BIOL. Sci. 3: 778-784.

White, J. W., Bryant, V. M., and Jones, J. G. 1991. Adulteration Testing of Southwestern Desert Honeys. American Bee Journal 131: 123-126. 